\title{
PENGEMBANGAN MODEL LATIHAN BUILD UP MENYERANG PADA PERMAINAN FUTSAL
}

\author{
Andri Paranoan \\ Ardi Nur Prastya \\ Program Studi D-III Ilmu Kepelatihan Olahraga, Akademi Olahraga Prestasi Nasional
Pendidikan Kepelatihan Olahraga, Universitas Negeri Jakarta \\ andri.paranoan@akornas.ac.id \\ prastyasay27@gmail.com
}

\begin{abstract}
ABSTRAK
Penelitian ini bertujuan untuk mengembangkan model latihan Build up menyerang pada permainan futsal menjadi sesuai dengan teori prinsip-prinsip Build up menyerang. Metode yang digunakan dalam penelitian ini adalah metode penelitian dan pengembangan (research and development). Subjek pada penelitian ini adalah 15 anggota tim futsal Kiangsantang sebagai subjek uji coba kelompok kecil dan 45 anggota tim futsal Universitas Negeri Jakarta sebagai subjek uji coba kelompok besar. Pada penelitian ini peneliti bekerja sama dengan 3 ahli dalam bidang olahraga futsal sebagai expert judgement. Uji validitas yang digunakan pada penelitian ini adalah dengan menggunakan uji justifikasi ahli. Berdasarkan uji validasi dari 25 item model latihan Build up menyerang pada permainan futsal didapat 20 model latihan Build up yang valid berdasarkan uji justifikasi ahli
\end{abstract}

\section{Kata Kunci : Model Latihan, Build Up, Futsal}

\section{ABSTRACT}

This study aims to develop a Build up attacking model on futsal games to be in line with the theory of Build up attacking principles. The method used in this research is the method of research and development (research and development). Subjects in this study were 15 members of Kiangsantang futsal team as the subject of small group trials and 45 members of futsal team of Universitas Negeri Jakarta as subject of large group trials. In this study the researchers worked together with 3 experts in the field of futsal sport as an expert judgment. Validity test used in this research is by using expert justification test. Based on the validation test of 25 items of training model Build up attack on futsal game obtained 20 models of valid Build up exercise based on expert justification test.

\section{Keywords: Exercise Model, Build Up, Futsal}

\section{PENDAHULUAN}

Taktik dan strategi merupakan salah satu faktor prestasi dalam olahraga, terutama bagi olahraga permainan tim. Tim yang memiliki taktik dan strategi yang baik mampu menguasai jalanya permainan. Lawan akan sulit mengantisipasi jika sebuah tim memilik taktik dan strategi yang baik. Taktik dan strategi yang baik dalam sebuah tim akan membentuk permainan tim yang solid, sehingga memiliki kesempatan untuk memenangkan sebuah pertandingan. Taktik dan strategi akan berjalan dengan baik dalam pertandingan jika setiap pemain menguasai dan memahami taktik dan strategi yang akan diterapkan. Kerjasama yang baik antar pemain di dalam sebuah tim akan memudahkan untuk menjalankan taktik dan strategi yang telah ditetetepkan oleh pelatih.

Strategi menyerang dengan cara membangun serangan dari bawah dalam 
permainan futsal disebut dengan Build up. Tim yang menerapkan strategi Build up dalam permainan dapat menguasai bola selama mungkin, sehingga bisa membongkar pertahanan lawan dan menciptakan peluang untuk mencetak gol. Strategi Build up juga dapat dilakukan untuk keluar dari presure tim lawan tanpa harus langsung memberikan bola menuju pemain pivot. Strategi Build up dapat berjalan dengan baik jika setiap pemain memahami dan menguasai straregi Build up yang akan diterapkan.

Sanusi (2009) Latihan yang dibuat harus efektif dan bervariasi untuk memudahkan pemain dalam menerapkan strategi pada saat pertandingan, latihan yang dilakukan secara tidak tepat akan mempengaruhi perkembangan atlet baik secara fisiologi ataupun psikologi. Pada prinsipnya latihan merupakan suatu proses perubahan kearah yang lebih baik, yaitu untuk meningkatkan kualitas fisik, kemampuan fungsional peralatan tubuh, dan kualitas psikis anak latih atau atlet. Permainan futsal dapat berjalan dengan baik pada saat pertandingan jika pelatih memiliki banyak variasi model-model latihan terutama pada model atau bentuk latihan.

Jhon D. Tenang (2008) Futsal adalah singkatan dari futbol (sepakbola) dan sala (ruangan) dari bahasa Spanyol atau futebol (Portugal/Brasil) dan salon (Prancis) yang berarti sepakbola dalam ruangan. Menurut Justinus (2008) futsal adalah olahraga permainan yang dimainkan lima lawan lima dengan lapangan yang tidak luas dan memakai bola ringan. Sedangkan menurut Andri (2009) Permainan futsal merupakan permainan yang mempunyai satu tujuan yaitu mencetak gol dan berusaha untuk mencegah lawan membuat gol dengan cara yang sesuai dengan peraturan permainan. Andri (2008) juga menjelaskan bahwa Permainan futsal mengharuskan pemain untuk memiliki teknik dasar yang baik karena sirkulasi bola dalam permainan futsal sangat cepat. Teknik dasar dalam permainan futsal diantaranya seperti mengumpan (passing), menerima (receiving), mengumpan lambung (chipping), menggiring (dribbling), menembak (shooting), dan menyundul (heading).

Bagian utama dalam bermain futsal ialah memenangkan sebuah pertandingan tersebut, adanya proses memenangkan pertandingan yaitu melakukan sebuah penyerangan yang bisa berawal dari serangan balik yang cepat, antisipasi, dan membangun serangan dari bawah atau disebut Build up. Build up merupakan hal yang sering dilupakan untuk dilatih atau diajarkan. Build up yang dimaksud adalah membangun serangan dari bawah pertahanan sendiri dan tidak memaksakan permainan untuk terburu-buru menyerang ke pertahanan lawan dimana saat pertahanan lawan seimbang. Menurut Timo Build up berfungsi juga untuk mengatur pertandingan dimana saat Build up tim yang melakukan ini bisa menguasai pertandingan atau mengatur tempo pertandingan dan adapun membangun serangan dari bawah (Build up play from the back) adalah sebuah usaha bersama untuk mengirimkan bola dari daerah pertahanan menuju ke daerah penyerangan melalui serangkaian umpan pendek dan sedang (tidak langsung mengumpan jauh ke depan).

Rahmad Darmawan (2012)

mengatakan bahwa build up play adalah bagian dari sepakbola possession mana bergantung kepada kemampuan tim mengeksploitasi ruang (space). Baik ruang dibelakang garis pertahanan, di depan, di samping maupun space diantara pemainpemain lawan atau antar lini lawan. Build up play mempunyai bermacam - macam kombinasi dalam distirbusi taktik tersebut yaitu 1) memberikan passing jauh dengan kedalaman ke pemain terdepan yaitu striker untuk mencetak gol dimana build up ini mempunyai kerugian yaitu passing jauh yang kemungkinan diterima dengan skala 50:50 dengan pemain lawan, selain itu 2) melakukan dribbling atau drive dan disertai dengan passing pendek ke pemain dengan kelebaran lapangan sambil menunggu untuk kemungkinan melakukan passing kedalaman yang tidak bisa diambil oleh pemain lawan dan di akhiri dengan mencetak gol. 


\section{METODE PENELITIAN}

Penelitian ini berupa model latihan build up pada permainan futsal. Selain itu, penelitian ini akan menghasilkan produk berupa desain model latihan build up yang lengkap dengan penjelasan dari setiap model yang telah dibuat. Model latihan build up ini akan dibuat menjadi sebuah buku yang dapat dijadikan sebagai bahan referensi bagi para pelatih dan pemain.

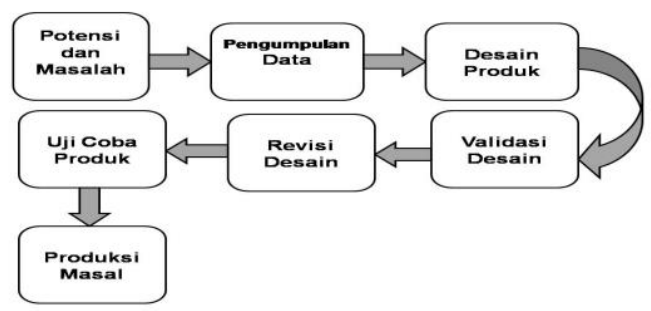

Gambar1: Bagan Rancangan Model Flow Chart

Sumber : Sugiyono,"Metode Penelitian Pendidikan, Pendekatan Kuantitatif, Kualitatif, dan R\&D,"(Bandung: Alfabeta, 2011), h.40

Agar rancangan model dapat berjalan dengan baik dan benar, maka penelitian ini akan menggunakan alur rancangan model yang digambarkan dalam bagan seperti dikutip dari Sugiyono, sebagai berikut:

\section{A. Langkah-langkah Pengembangan Model}

1. Potensi dan Masalah

Build up dalam permainan futsal merupakan salah satu cara untuk membongkar pertahanan lawan, sehingga memiliki potensi untuk mecetak gol. Jika sebuah tim mampu membangun serangan dengan baik maka, lawan akan kesulitan untuk merebut bola. Build up dalam permainan futsal dapat dilakukan apabila tim lawan menerapkan zona defence, sehingga serangan dapat dimulai dari bawah. Build up juga menjadi salah satu cara untuk dapat keluar dari tekanan lawan, jika tim lawan melakukan pressure.

Build up dalam permainan futsal masih jarang terlihat dilakukan oleh tim-tim yang berada di Indonesia, karena kecenderungan tim di Indonesia masih sering melakukan serangan dengan langsung menuju ke pemain pivot tanpa memulainya dengan cara membangun serangan dari bawah.
Menyerang dengan langsung mengarahkan bola ke depan atau ke pemain pivot akan menjadi sia-sia jika pemain pivot tidak memiliki kemampuan individu yang baik. Masalah ini dapat di atasi dengan cara memperbanyak variasi model latihan build up, sehingga pola serangan yang dilakukan akan berjalan dengan baik yang dimulai dari bawah untuk membongkar pertahanan lawan dan dapat menciptakan peluang untuk mencetak gol.

\section{Pengumpulan Data}

Penelitian ini akan membuat produk berupa model latihan build up pada permainan futsal. Peneliti memerlukan informasi atau data tentang cara build up yang dilakukan oleh beberapa tim pada pertandingan futsal dengan cara menganalisis pertandingan baik secara langsung ke venue pertandingan atau melihat video pertandingan.

\section{Desain Produk}

Berdasarkan potensi dan masalah serta pengumpulan data yang terkait dengan build up pada permainan futsal, maka untuk menghasilkan produk berupa model latihan build up, peneliti harus membuat rancangan model latihan build up terlebih dahulu. Rancangan model latihan build up ini nantinya akan dibuat dalam bentuk storyboard script yang menyajikan bentukbentuk model latihan build up untuk dianalisis dan dikoreksi terlebih dahulu oleh pembimbing dan para ahli.

\section{Validasi Desain}

Setelah penyusunan desain produk build up pada permainan futsal, desain tersebut akan dinilai apakah model latihan build up yang dibuat bersifat relevan yaitu yang sesuai dengan kejadian di dalam pertandingan. Validasi produk ini peneliti akan bekerja sama dengan ahli yang berkompeten di bidang olahraga futsal yaitu dosen dan kepala pelatih futsal.

\section{Revisi Desain}

Setelah desain produk di validasi melalui penilaian dan diskusi dengan para ahli, maka diketahui kelemahan dan kesalahan dari model latihan build up yang telah dibuat. Kelemahan dan kesalahan tersebut selanjutnya akan dikurangi dengan cara memperbaiki desain yang dilakukan oleh peneliti. 
6. Uji Coba Produk

Tahap uji coba model merupakan bagian penting dalam penelitian dan pengembangan, yang disesuaikan setelah pengembangan model latihan selesai dilakukan. Uji coba model bertujuan untuk mengetahui apakah model yang dikembangkan layak digunakan atau tidak. Uji coba model juga melihat sejauh mana produk yang dibuat mencapai sasaran dan tujuan. Uji coba dilakukan dua kali, yaitu (1) uji coba terbatas dilakukan terhadap kelompok kecil sebagai pengguna model, (2) uji coba lapangan.

Adapun dua tahapan dalam uji coba model latihan build up pada permainan futsal ini meliputi :

a. Uji coba terbatas, dilakukan terhadap kelompok kecil sebagai model. Hasil data dan uji coba kelompok kecil di analisis oleh pakar atau ahli di bidang futsal tersebut, selanjutnya dijadikan sebagai landasan untuk merivisi model latihan build up sebelum dilakukan uji coba lapangan untuk kelompok besar.

b. Uji coba lapangan (field testing), dilakukan terhadap kelompok besar sebagai model, selanjutnya dilakukan revisi kembali oleh para ahli dan dijadikan sebagai produk berupa model akhir latihan build up pada permainan futsal.

7. Validitas Ahli

Uji validitas dilakukan dengan tujuan untuk mengetahui sejauh mana model latihan yang dibuat layak untuk digunakan. Berdasarkan hal ini maka uji validitas dari model latihan ini adalah dengan menggunakan uji justifikasi ahli, dimana model latihan yang telah dibuat dan diuji cobakan kemudian dikonsultasikan dan dinilai oleh para ahli dalam bidang olahraga futsal. Ahli futsal untuk memvalidasi model latihan ini harus memiliki karakteristik, antara lain: (1) memiliki lisensi kepelatihan tingkat asia dan (2) memiliki pengalaman melatih minimal 3 tahun ditingkat nasional.

8. Implementasi Model

Implementasi produk hasil akhir penelitian riset dan pengembangan model berupa pengembangan baru latihan buildup menyerang permainan futsal dapat dipergunakan pada saat proses latihan setelah kelayakan dan keefektifan model latihan buildup dapat digunakan dan diimplementasikan pada para pelatih klub futsal. Pengembang model latihan buildup dapat di analisis kembali dan dijadikan bahan baru untuk penyempurnaan kembali.

Semua model yang telah di uji cobakan dalam kelompok kecil dan besar dan di validasi oleh ahli dapat di implementasikan untuk atlet profesional dan atlet amatir. Sehingga model latihan build up pada permainan futsal ini dapat dijadikan bahan referensi bagi para pelatih.

\section{HASIL PENELITIAN}

Adapun tujuan dari penelitian yang akan dibuat oleh peneliti adalah untuk mengembangkan model latihan build up pada permainan futsal yang lebih bervariatif dan inovatif. Tempat penelitian akan dilaksanakan di Kampus B Fakultas Ilmu Keolahragaan, Universitas Negeri Jakarta. Tempat pengambilan data pada penelitian ini dilaksanakan di Pondok Bambu Futsal, Jakarta Timur, dan di Tifosi Sport Centre, Duren Sawit, Jakarta. Waktu penelitian ini dilaksanakan pada bulan Agustus 2017 sampai dengan Januari 2018. Waktu pengambilan data akan dilaksanakan pada tanggal 16 Nopember dan 19 Desember 2017. Penelitian ini berupa model latihan build up pada permainan futsal. Selain itu, penelitian ini akan menghasilkan produk berupa desain model latihan build up yang lengkap dengan penjelasan dari setiap model yang telah dibuat. Model latihan build up ini akan dibuat menjadi sebuah buku yang dapat dijadikan sebagai bahan referensi bagi para pelatih dan pemain.

Uji validitas dilakukan dengan tujuan untuk mengetahui sejauh mana model latihan yang dibuat layak untuk digunakan. Berdasarkan hal ini maka uji validitas dari model latihan ini adalah dengan menggunakan uji justifikasi ahli, dimana model latihan yang telah dibuat dan diuji cobakan kemudian dikonsultasikan dan dinilai oleh para ahli dalam bidang olahraga futsal. Ahli futsal untuk memvalidasi model latihan ini harus memiliki karakteristik, antara lain: (1) memiliki lisensi kepelatihan tingkat asia dan (2) memiliki pengalaman melatih 
minimal 3 tahun ditingkat nasional. Pengembangan model pada penelitian ini tertulis dalam bentuk naskah atau storyboard script yang menyajikan bentukbentuk latihan futsal yang dikembangkan untuk memberikan variasi model latihan build up yang dapat dijadikan bahan referensi bagi para pelatih futsal dalam menyusun program latihan. Setelah diadakan penelitian yang dilaksanakan pada tanggal Agustus 2017 sampai dengan Januari 2018.

Berdasarkan hasil diskusi dan evaluasi yang telah dilakukan, maka diadakan uji coba kelompok kecil dengan jumlah 15 subjek. Uji coba kelompok kecil diadakan pada tanggal 16 Nopember 2017 bertempat di Pondok Bambu Futsal, Jakarta. Subjek uji coba kelompok kecil pada penelitian ini yaitu anggota Academy Futsal Kiansantang. Pada uji coba kelompok kecil, peneliti mengundang para ahli untuk hadir kemudian melihat, menilai, dan memutuskan setiap item model yang telah dibuat, apakah model latihan build up yang dibuat layak dan dapat digunakan sebagai model latihan futsal. Setelah diadakan uji coba kelompok kecil yang dilihat serta dinilai oleh para ahli, maka berdasarkan hasil kesepakatan dari para ahli telah diputuskan model latihan build up pada cabang olahraga futsal adalah sebanyak 20 item model.

\section{Model latihan Build Up menyerang} session 1

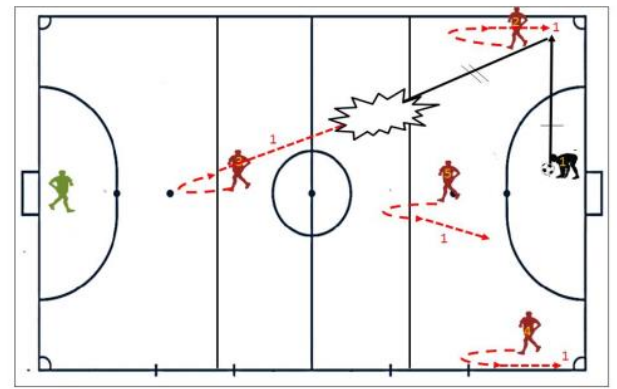



Gambar.1 Model Latihan Build Up Menyerang session 1 Sumber : Desain Peneliti

\section{a. Cara pelaksanaan :}

Pemain nomor 2, 3, 4 dan 5 melakukan pergerakan breakc run dan pemain nomor 2 menerima bola dari penjaga gawang dan dilanjutkan passing ke nomor 3

\section{b. Penjelasan :}

Semua pemain melakukan pergerakan breakc run atau menjauhkan diri dari lawan sehingga menciptakan ruang untuk diri sendiri seingga tercipta ruangan di area kreative play.

\section{Model latihan Build up menyerang} session 2
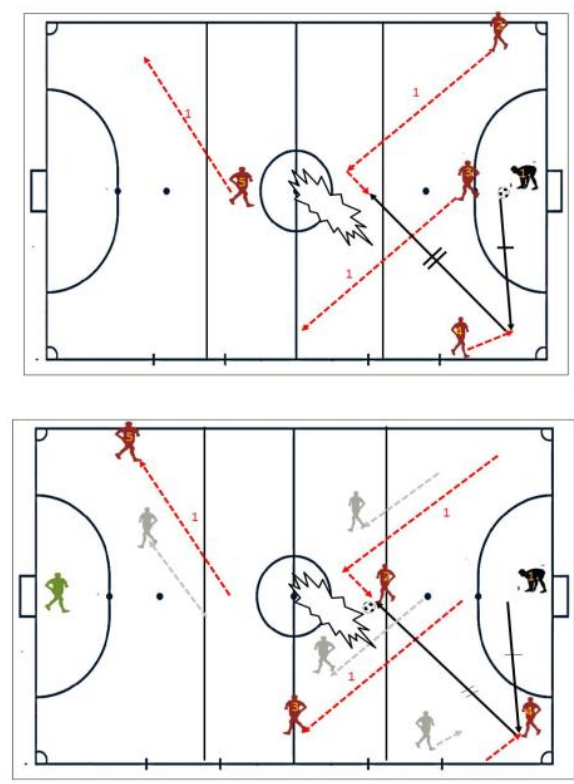

Gambar.2 Model Latihan Build Up

Menyerang session 2

Sumber : Desain Peneliti 


\section{a. Cara pelaksanaan :}

Pemain melakukan lari diagonal pemain nomor 2 dan 3 bersama-sama pemain nomor 4 bersiap menerima bola yang distribusikan oleh penjaga gawang dan kemudian melakukan passing ke pemain no 2, pemain nomor 5 membuka ruang untuk pemain nomor 2 sehinga pemain mendapatkan ruang yang sangat terbuka.

\section{b. Penjelasan:}

> Pemain nomor 4 memposisikan menerima bola dari penjaga gawang dan passing ke pemain no 2 .

$>$ Pemain nomor 3 berlari diagonal fungsinya untuk pengalihan untuk pemain nomor 2 .

3. Model latihan build up menyerang session 3
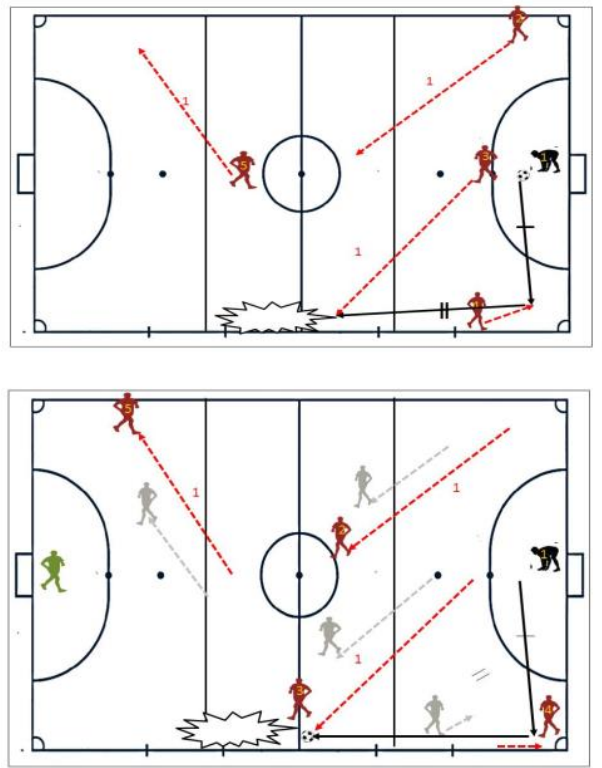

Gambar.3 Model Latihan Build Up

Menyerang session 3

Sumber : Desain Peneliti

\section{a. Cara pelaksanaan :}

Sama dengan pergerakan model sebelumnya pemain nomor 2 dan 3 berlari diagonal secara bersama-sama nomor 5 berlari diagonal sebaliknya dan pemain nomor 4 bersiap memposisikan menerima bola saat bola distribusikan oleh penjaga gawang,dan pemain nomor 4 passing pararel ke pemain nomor 3 .

\section{b. Penjelasan :}

Pemain nomor 4 memposisikan menerima bola dari penjaga gawang dan passing pararel ke pemain nomor 3

$>$ Pemain nomor 3 berlari diagonal bersiap menerima bola dari pemain nomor 4.

4. Model latihan build up menyerang session 4
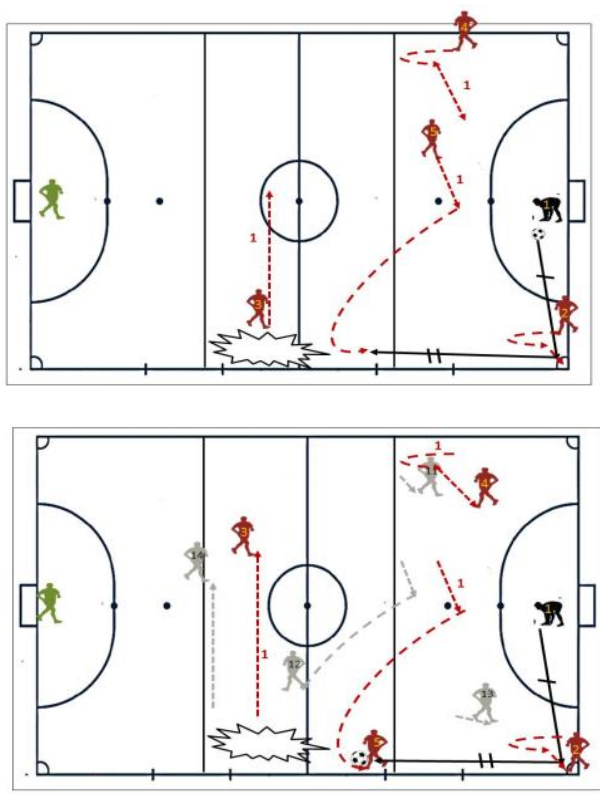

Gambar.4 Model Latihan Build Up Menyerang session 4

Sumber : Desain Peneliti

\section{a. Cara pelaksanaan :}

Pemain nomor 2 dan 4 melakukan breakcrun dan pemain nomor 5 berlari diagonal dan penjaga gawang mendistribusikan bola ke pemain nomor 2, kemudian passing pararel ke pemain nomor 5 pemain nomor 3 berlari membuka ruang untuk pemain nomor 5 .

\section{b. Penjelasan :}

$>$ Pemain nomor 2 breakrun dan menerima bola dari penjaga gawang dan memposisikan untuk passing ke pemain nomor 5 .

$>$ Pemain nomor 4 breakrun dan berlari kedalam untuk melakukan cover kepada pemain tengah.

$>$ Pemain nomor 3 berlari untuk membuka ruang untuk pemain nomor 5. 


\section{Model latihan build up menyerang} session 5
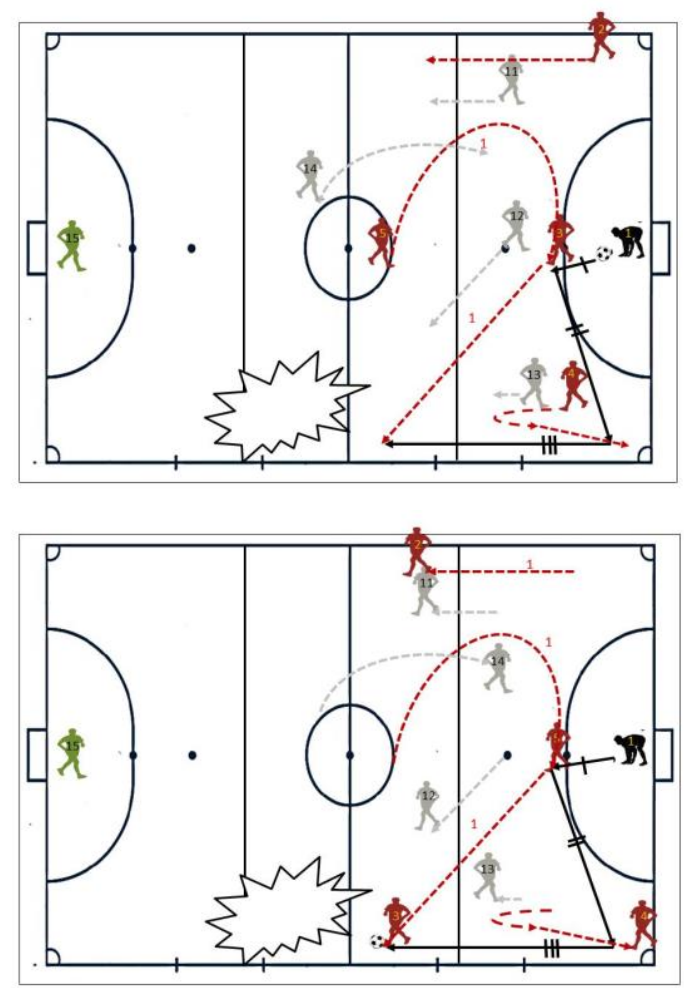

Gambar.5 Model Latihan Build Up

Menyerang session 5

Sumber : Desain Peneliti

\section{a. Cara pelaksanaan :}

Pemain nomor 3 berlari diagonal ,pemain nomor 5 menggantikan posisi pemain nomor 3 dan menerima bola dari penjaga gawang, kemudian passing ke pemain nomor 4 dan langsung passing ke pemain nomor 3 dan pemain nomor 2 suport kedepan.

\section{b. Penjelasan :}

Secara bersamaan pemain nomor 5 mengisi posisi awal pemain nomor 3 .

> Pemain nomor 4 breakrun dan bersiap memposisikan menerima bola dari penjaga gawang.

$>$ Kiper memberikan ke pmain nomor 5 kemudian passing ke pemain no 4 dan passing ke pemain nomor 3 .

Pemain nomor 2 mensuport saat pemain Nomor 3 sudah menerima bola.
6. Model latihan build up menyerang session 6
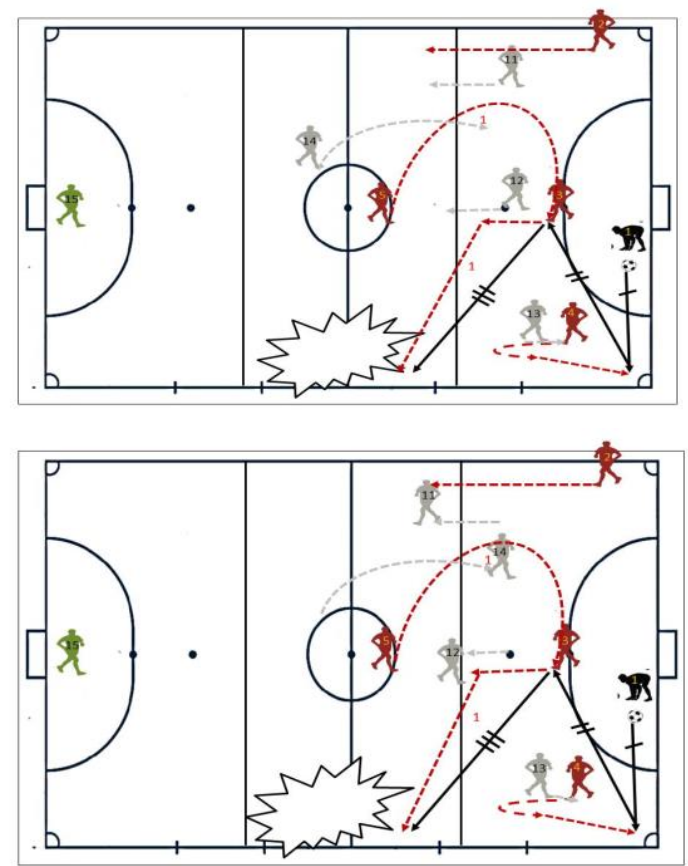

Gambar.6 Model Latihan Build Up

Menyerang session 6

Sumber : Desain Peneliti

\section{a. Cara pelaksanaan:}

Pemain nomor 3 lari kedepan lalu diagonal, pemain nomor 5 menggantikan posisi pemain nomor 3 , pemain nomor 4 melakukan melakukan wallpass dengan pemain nomor 3 .

\section{b. Penjelasan :}

$>$ Pemain nomor 3 berlari lurus kemudian diagonal.

$>$ Pemain nomor 4 breakrun dan memposisikan untuk menerima bola dari penjaga gawang.

Pemain nomor 5 berlari ke arah posisi awal nomor 3 dan melakukan wallpass. 
7. Model latihan build up menyerang session
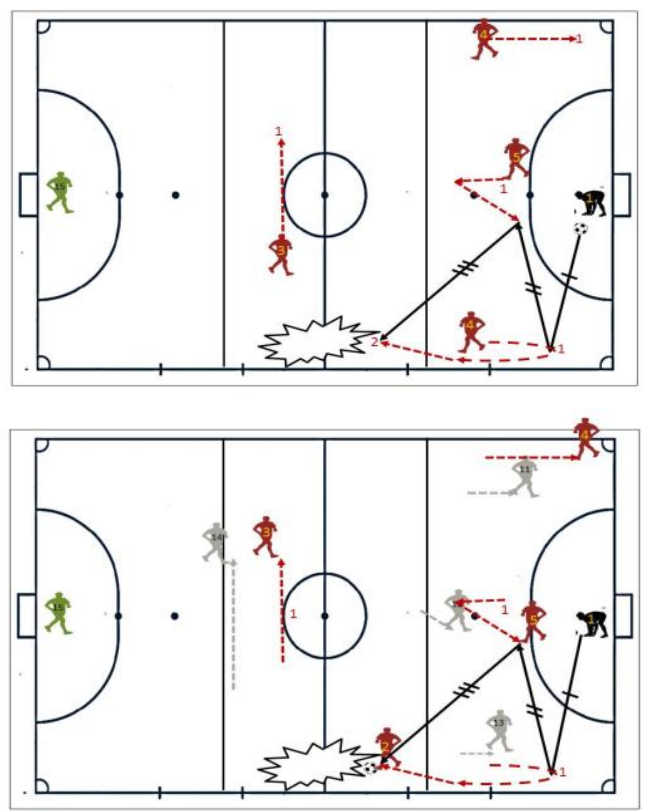

Gambar.7 Model Latihan Build Up

Menyerang session 7

Sumber : Desain Peneliti

\section{a. Cara pelaksanaan :}

Pemain nomor 2 bergerak brakc run dan penjaga gawang mendistribusikan kemudian melakukan wallpass pemain nomor 2 dan 5 .

b. Penjelasan :

$>$ Pemain nomor 2 break run dan menerima bola dari penjagawa gawang.

$>$.pemain nomor 5 lari lurus membawa lawan kemudiann kembali lagi untuk melakukan wallpass dengan nomor 2 .

$>$ Pemain nomor 3 berlari untuk membuka ruang.

8. Model latihan build up menyerang session 8

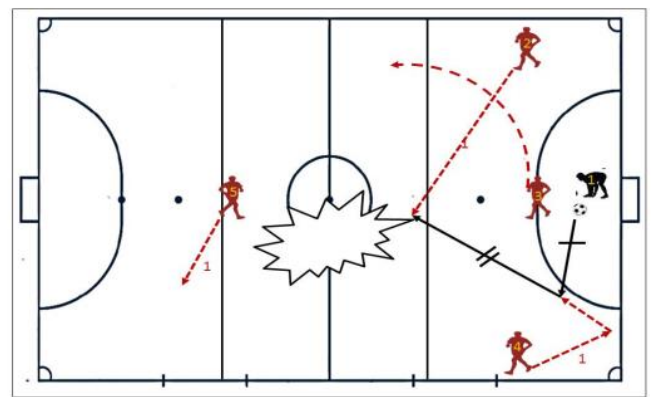

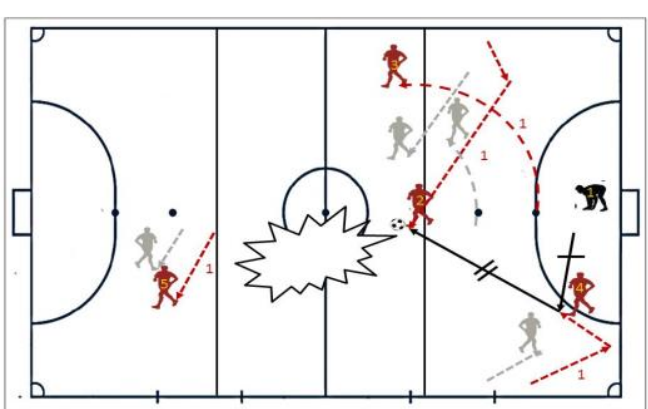

Gambar.8 Model Latihan Build Up

Menyerang session 8

Sumber : Desain Peneliti

a. Cara pelaksanaan :

Pemain nomor 4 memposisikan untuk menerima bola dari penjaga gawang kemudian pemain nomor 2 memposisikan untuk menerima bola dari pemain nomor 4 , pemain nomor 3 berlari kearah belakang pemain nomor 2 dan menahan jalur lari lawan nomor 4

\section{b. Penjelasan :}

$>$ Pemain nomor 4 berlari kebawah dan memposisikan menerima bola dari penjaga gawang.

> Pemain nomor 3 berlari arah belakang pemain nomor 2

$>$ Pemain nomor 2 berlari kedalam kemudian diagonal dan menerima bola dari pemain nomor 4 .

\section{Model latihan build up menyerang session 9}



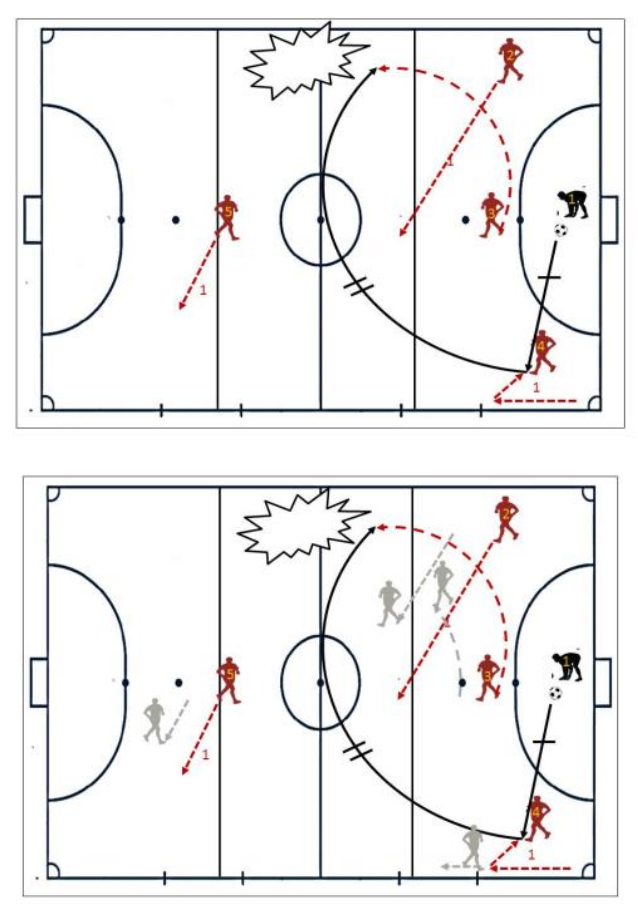

Gambar.9 Model Latihan Build Up

Menyerang session 9

Sumber : Desain Peneliti

\section{a. Cara pelaksanaan :}

Pemain nomor 4 memposisikan menerima bola dari penjaga gawang, pemain nomor 2 berlari diagonal ketengah dan pemain nomor 3 brlari ke arah belakang pemain nomor 2 dan memposisikan untuk menerima bola, pemain nomor 5 membuka ruang.

\section{b. Penjelasan : \\ $>$ Pemain nomor 4 mempersiapkan menerima dari penjaga gawang dengan berlari kedepan dan kedalam.}

$>$ Pemain nomor 2 berlari diagonal ketengah.

$>$ Pemain nomor 3 berlari dari belakang pemain nomor 2 dan menerima bola dari pemain nomor 4

- Pemain nomor 5 membuka ruang untuk pemain nomoer 3 .

\section{Model latihan Build up menyerang session 10}
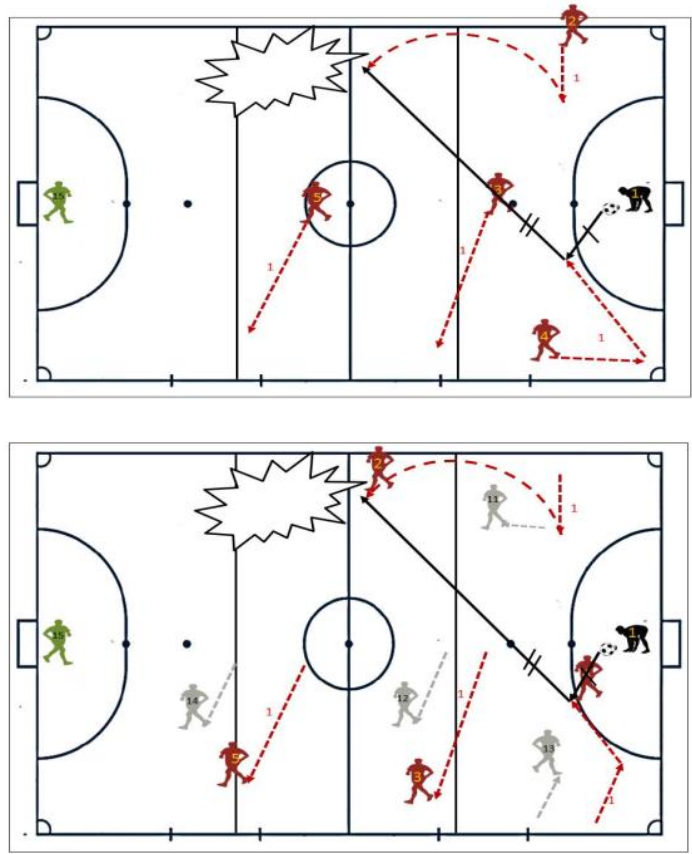

Gambar.10 Model Latihan Build Up

Menyerang session 10

Sumber : Desain Peneliti

\section{a. Cara pelaksanaan :}

Pemain nomor 4 berlari kebelakang dan menerima dari penjaga gawang, pemain nomoe 3 dan 5 berlari diagonal dan pemain nomor 2 berlari kedalam lalu keluar dan siap menerima bola dari pemain nomor 4 .

\section{b. Penjelasan :}

> Pemain nomor 4 berlari kebawah dan menerima bola yang. didistribusikan oleh penjaga gawang kemudian passing ke pemain nomor 2 .

$>$ Pemain nomor 3 yang berada ditengah berlari diagonal dan membawa lawan.

$>$ Pemain nomor 5 yang berada di tengah berlari diagonal dan membawa lawan seperti yang dilakukan pemain nomor 3.

$>$ Pemain nomor 2 berlari kedalam lalu keluar dan memposisikan untuk menerima bola. 
11. Model latihan build up menyerang session 11
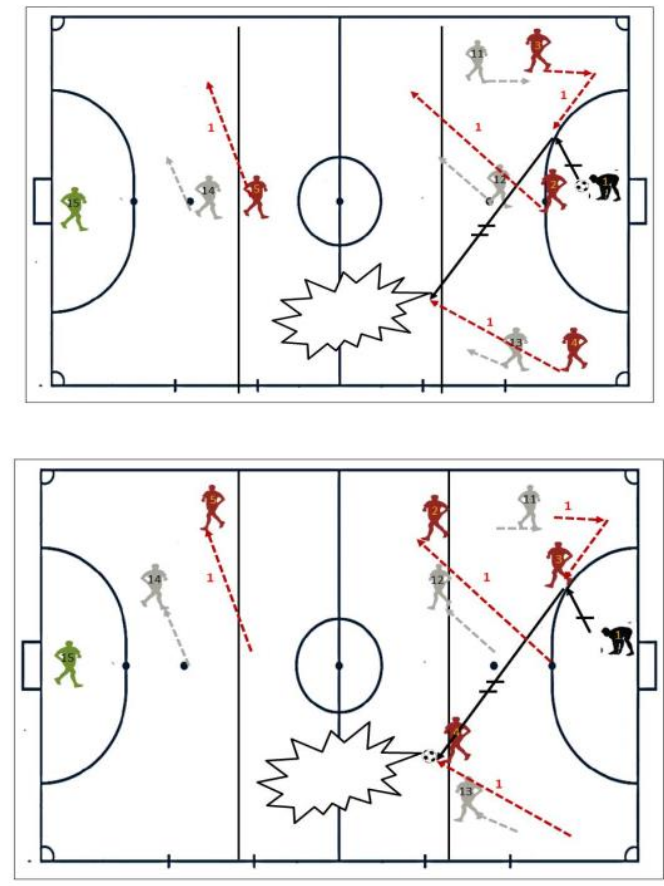

Gambar.11 Model Latihan Build Up

Menyerang session 11

Sumber : Desain Peneliti

\section{a. Cara pelaksanaan :}

Pemain nomor 3 berlari kebawah untuk menghindari lawan dan berlari diagonal kekiri utuk menerima bola dari penjaga gawang kemudian mengumpan bola ke pemain nomor 4 , pemain nomor 4 berlari kedepan untuk meneria bola, bersamaan dengan pemain nomor 4 pemain nomor 2 juga berlari kedepan juga dan pemain nomor 5 berlari diagonal kekanan

\section{b. Penjelasan}

:

$>$ Pemain nomor 3 berlari kebawah dan berlari diagonal kekiri untuk merima bola yang didistribusikan oleh penjaga gawang kemudian passing ke pemain nomor 4.

$>$ Pemain nomor 4 yang berada dikiri berlari diagonal ke kanan dan membawa lawan.

$>$ Pemain nomor 2 yang berada di tengah berlari diagonal dan membawa lawan seperti yang dilakukan pemain nomor 4.

Pemain nomor 5 berlari keluar lalu memposisikan diri untuk menerima bola.

\section{Model latihan build up menyerang session 12}
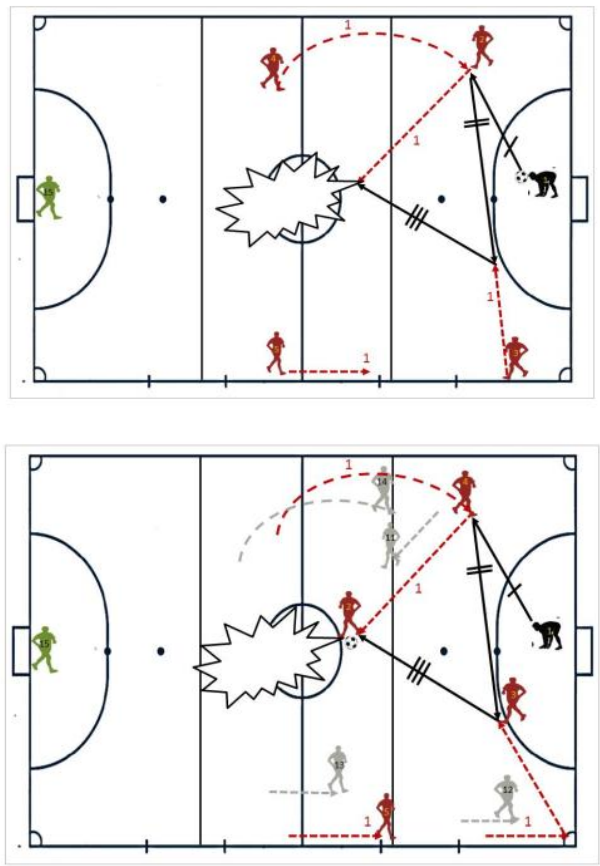

Gambar.12 Model Latihan Build Up

Menyerang session 12

Sumber : Desain Peneliti

\section{a. Cara pelaksanaan :}

Pemain nomor 2 berlari diagonal kekiri, di ikuti dengan pemain nomor 3 yang berlari diagonal kekanan, kemudian pemain nomor 4 berlari melambung kebawah untuk menerima bola dari penjaga gawang dan di ikuti oleh pemain nomor 5 yang berlari kebawah

\section{b. Penjelasan :}

Pemain nomor 2 berlari diagonal kekiri untuk menarik lawan.

> Pemain nomor 3 berlari kebelakang terlebih dahulu dan dilanjutkan dengan berlari diagonal kekanan untuk mengecoh lawan.

$>$ Pemain nomor 4 berlari melambung dari atas kebawah untuk menerima bola dari penjaga gawang.

$>$ Pemain nomor 5 berlari diagonal dari atas ke bawah. 
13. Model latihan build up menyerang session 13
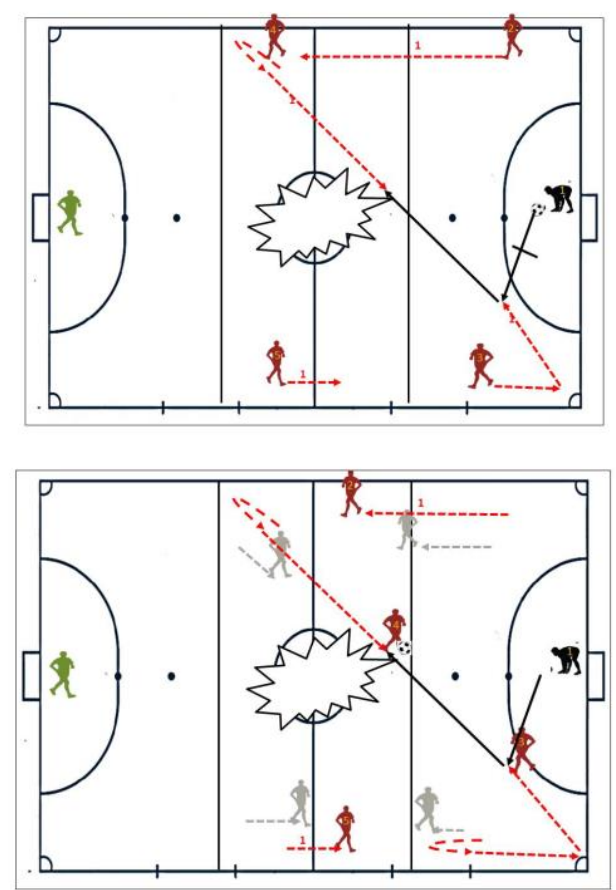

Gambar.13 Model Latihan Build Up

Menyerang session 13

Sumber : Desain Peneliti

\section{a. Cara pelaksanaan:}

Pemain nomor 2 berlari kedepan untuk membawa lawan, pemain nomor 3 berlari kebelakang dan didilanjutkan dengan gerakan diagonal ke kanan bersamaan dengan pemain nomor 4 yang berlari diagonal ke kiri bawah, dan pemain nomor 5 berlari kebawah untuk bersiap menerima bola.

\section{b. Penjelasan}

\section{:}

Pemain nomor 2 berlari dari bawah ke atas untuk membawa lawan.

$>$ Pemain nomor 3 berlari ke bawah dengan gerak tipuan ke depan dan di lanjutkan dengan berlari diagonal ke kanan untuk menerima bola dari penjaga gawang.

> Pemain nomor 4 berlari ke bawah dengan gerak tipuan ke depan dan di lanjutkan dengan berlari diagonal ke kanan bawah untuk menerima bola dari pemain nomor 3 .

Pemai nomor 5 berlari kebawah untuk siap-siap dalam menerima bola.
14. Model latihan build up menyerang session 14
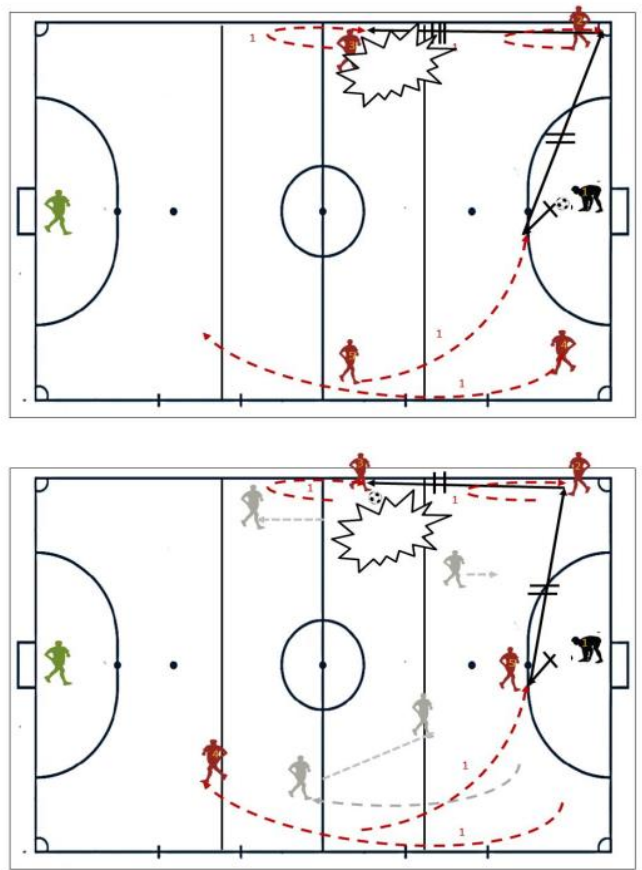

Gambar.14 Model Latihan Build Up

Menyerang session 14

Sumber : Desain Peneliti

\section{a. Cara pelaksanaan :}

Pemain Pemain nomor 4 berlari melambung dari bawah ke atas bersamaan dengan pemain nomor 5 yang berlari melambung dari atas ke bawah untuk menerima bola dari penjaga gawang, sedangkan pemain nomor 2 dan 3 berlari memutar ke bawah untuk menerima bola dari pemain nomor 5 dan 2 .

\section{b. Penjelasan :}

$>$ Pemain nomor 4 bergerak melambung dari sisi kiri ke bawah atas untuk menarik lawan.

$>$ Pemain nomor 5 bergerak melambung dari sisi kiri ke atas bawah untuk menerima bola dari penjaga gawang.

> Sedangkan pemain nomor 2 dan 3 berlari kedepan dan berputar kearah kanan bawah untuk menerima bola dari pemain nomor 5 dan 2 . 
15. Model latihan build up menyerang session 15
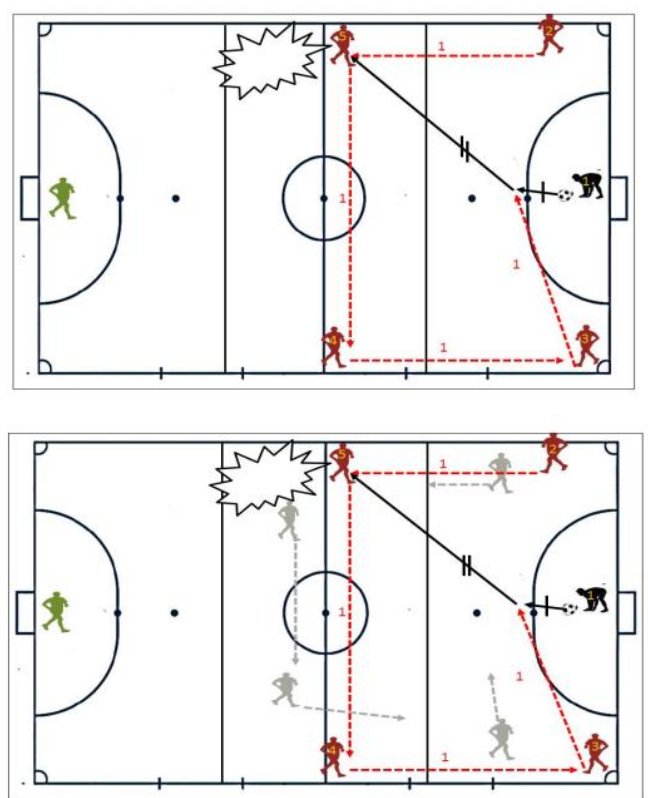

Gambar.15 Model Latihan Build Up

Menyerang session 15

Sumber : Desain Peneliti

\section{a. Cara pelaksanaan :}

Pemain nomor 2, 5, dan 4 berlari rotasi pemain nomor 3 berlari diagonal ke kanan untuk menerima bola dari penjaga gawang dan passing ke pemain nomor 2 .
b. Penjelasan

Pemain nomor 2 berlari ke posisi ke pemain nomor 5 .

$>$ Pemain nomor 5 berlari ke posisi nomor 4.

$>$ Pemain nomor 4 berlari ke posisi nomor 3.

$>$ Dan pemain nomor 3 berlari diagonal ke arah kanan ntuk menerima bola dari penjaga gawang dan passing ke pemain nomor 2 .

16. Model latihan build up menyerang session 16

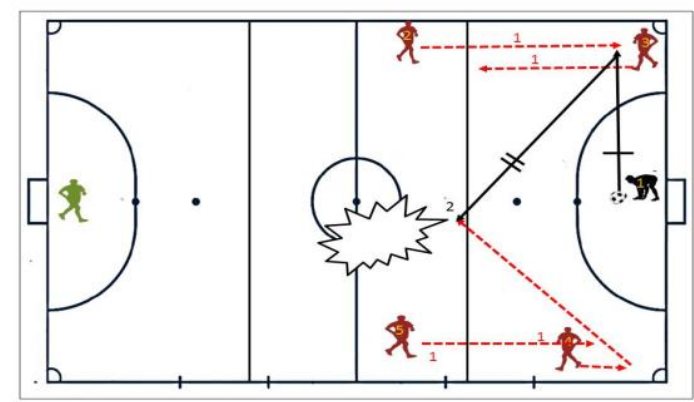

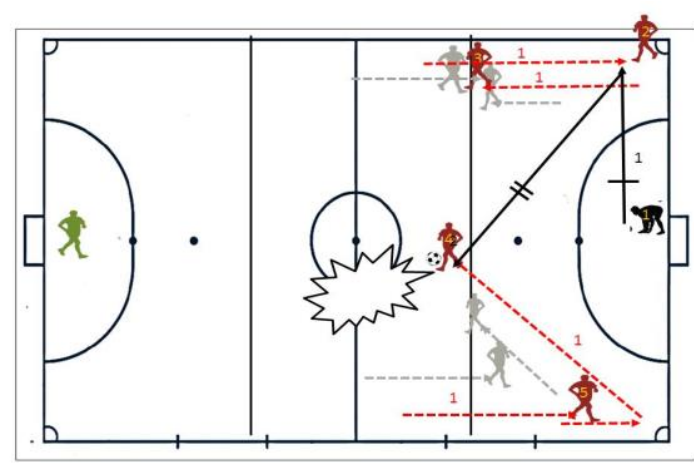

Gambar.16 Model Latihan Build Up

Menyerang session 16

Sumber : Desain Peneliti

\section{a. Cara pelaksanaan:}

Pemain nomor 3 dan 2 berlari bertukaran posisi dan pemain nomor 2 menerima bola dari penjaga gawang,pemain nomor 4 berlari keblakang kemudian lari diagonal ketengah dan bersiap menerima bola dari pemain nomor 2. Pemain nomor 5 berlari kebawah untuk mengcover

\section{b. Penjelasan :}

$>$ Pemain nomor 3 berlari kearah depan atau keposisi pemain nomor 2. dan menghambat lari pemain lawan nomor 3 .

$>\quad$ Pemain nomor 2 berlari kearah pemain nomor 3 dan menerima bola yang didistribusikan oleh penjaga gawang.

$>\quad$ Pemain nomor 4 berlari kebawah kemudian lari diagonal ke tengah dan menerima bola yang dipassing oleh pemain nomor 2 .

$>\quad$ Pemain nomor 5 berlari kebawah untuk mengcover pemain nomor 4 .

17. Model latihan build up menyerang session 17

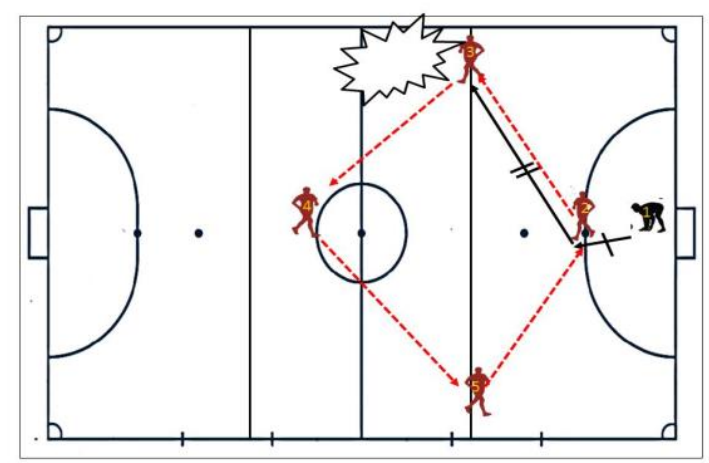




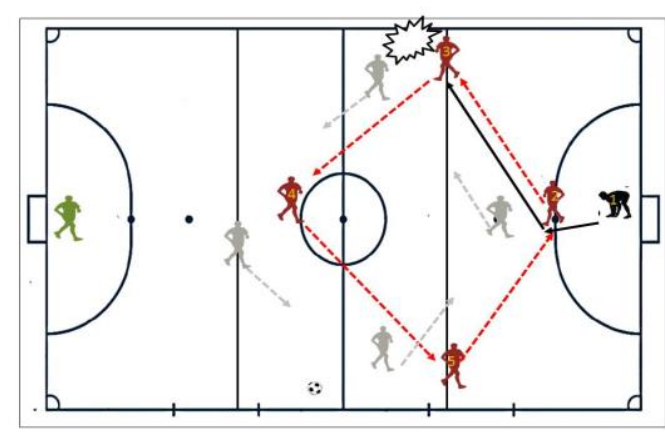

Gambar.17 Model Latihan Build Up

Menyerang session 17

Sumber : Desain Peneliti

\section{a. Cara pelaksanaan :}

Pemain nomor 2 berlari ke posisi pemain nomor 3 , pemain nomor 3 berlari ke posisi pemain nomor 4 , pemain nomor 4 berlari ke posisi pemain nomor 5 , pemain nomor 5 berlari ke posisi pemain nomor 2 dan menerima bola dari penjaga gawang dan diteruskan ke pemain nomor 2 .

\section{b. Penjelasan :}

Semua pemain melakukan rotasi untuk merubah posisi pemain, agar pemain lawan menjadi kesulitan dalam melakukan penjagaan.

\section{Model latihan build up menyerang} session 18
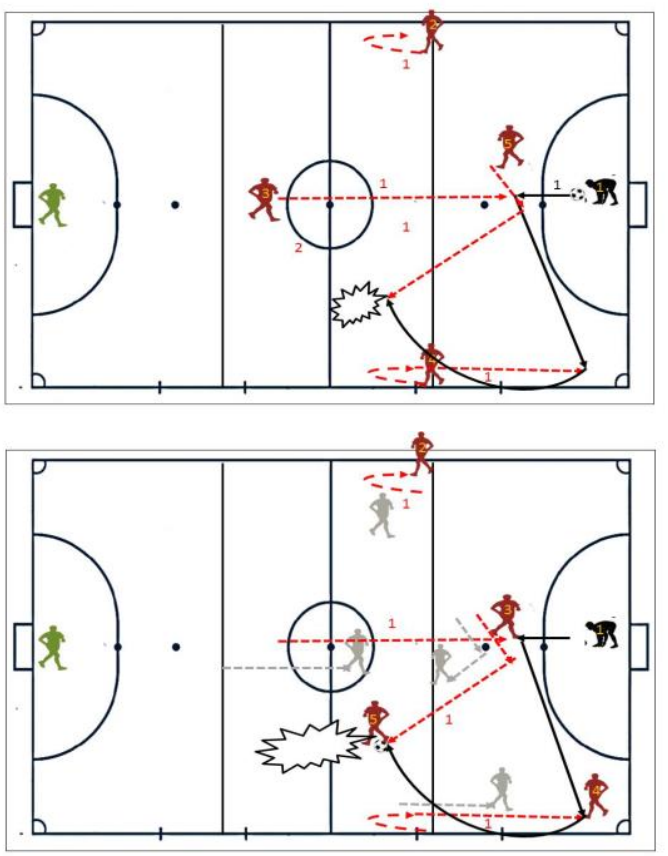

Gambar.18 Model Latihan Build Up

Menyerang session 18

Sumber : Desain Peneliti

\section{a. Cara pelaksanaan :}

Pemain nomor 5 berlari kedalam dan berlari diagonal, kemudian pemain nomor 3 berlari dan menerima dari penjaga gawang kemudian passing ke pemain nomor 4,pemain nomor 4 passing pararel ke pemain nomor 5 .

\section{b. Penjelasan :}

$>$ Pemain nomor 5 berlari kedalam kemudian lari diagonal.

$>$ Pemain nomor 3 berlari keposisi pemain nomor 5 dan menerima bola dari penjaga gawang.

$>$ Pemain nomor 4 melakukan breakc run dan memposisikan menerima bola yang dipassing oleh pemain nomor 3 kemudian passing pararel kepemain nomor 5.

$>$ Pemain nomor 2 brakcrun dan melakukan cover kepada.

19. Model latihan build up menyerang session 19
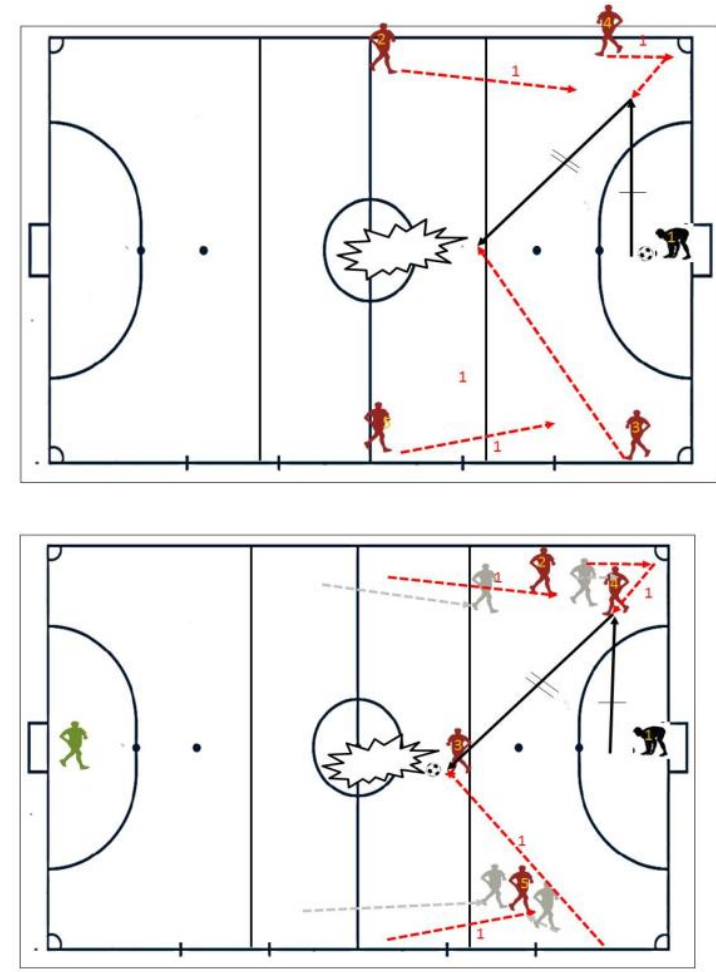

Gambar.19 Model Latihan Build Up

Menyerang session 19

Sumber : Desain Peneliti

\section{a. Cara pelaksanaan :}

Pemain nomor 2 dan 5 berlari kearah bawah dan menahan jalur lari lawan 4 dan 3, pemain nomor 3 berlari diagonal 
ketengah dan menerima bola dar pemain nomor 4.

\section{b. Penjelasan :}

$>$ Pemain nomor 2 berlari kearah lawan pemain nomor 4

$>$ Pemain nomor 5 berlari kearah lawan pemain nomor 3

$>$ Pemain nomor 4 berlari ke bawah dan menerima bola dari penjaga gawang kemudian ditruskan passing ke pemain nomor 3.

$>$ Pemain nomor 3 berlari diagonal ketengah untuk menerima bola dari pemain nomor 4 .

\section{Model latihan build up menyerang session 20}
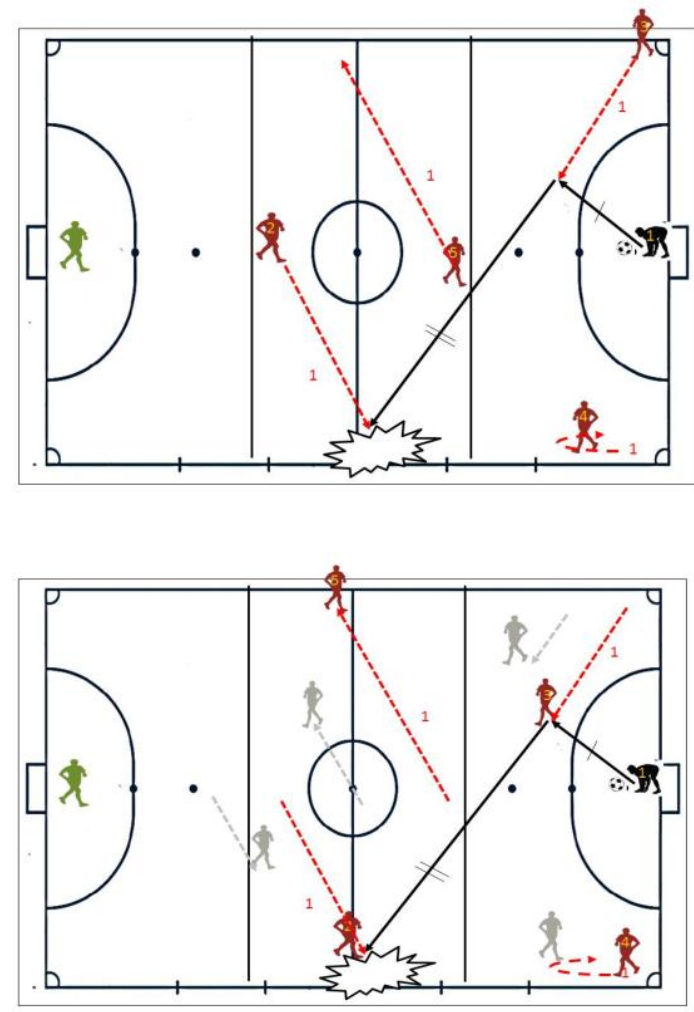

Gambar.20 Model Latihan Build Up

Menyerang session 20

Sumber : Desain Peneliti

\section{a. Cara pelaksanaan:}

Pemain nomor 2 berlari diagonal untuk mensuport, pemain nomor 5 membuka ruang,pemain nomor 1 memposisikan menerima bola kemudian passing ke pemain nomor 2, pemain nomor 4 break run. b. penjelasan:

$>$ pemain nomor 2 dan pemain nomor 5 berada di posisi lurus dengan kiper

$>$ pemain nomor berlari kebawah dan memposisikan menerima bola dari pemain nomor 3 .

$>$ Pemain nomor 3 menjemput bola yang didistribusikan oleh penjaga gawang kemudian passing ke pemain nomor 2 .

$>$ Pemain nomor 4 bergerak break run dan melakukan cover kepada pemain nomor 4 .

\section{KESIMPULAN}

Berdasarkan data yang diperoleh dari hasil uji coba lapangan dan pembahasan hasil penelitian dapat disimpulkan bahwa berdasarkan uji validasi dari 25 item model latihan buildup menyerang pada permainan futsal didapat 20 model latihan yang valid berdasarkan uji justifikasi ahli.

\section{DAFTAR PUSTAKA}

Andri Irawan. 2009. Teknik Dasar Modern Futsal. (Jakarta:Pena Pundi Aksara)

Eckner, Constantin. 2010. Tactical Theory Vertical Build Up Passing.

Hasibuan, Sanusi. 2009. Evaluasi Program Pembinaan Pusat Latihan Olahraga Pelajar di Kalimantan Timur, Riau Dan Sumatera Barat Tahun 2012.

Lhaksana, Justinus dan Ishak H. Pardosi. 2008. Inspirasi dan Spirit Futsal. (Jakarta: Raih Asa Sukses)

Luxbacher, Joseph. 2011. Sepakbola Edisi Kedua, (Jakarta:PT RajaGrafindo)

Margono. 2010. Metode Penelitian Pendidikan. (Jakarta:Rineka Cipta)

Nusa Putra. 2011. Reassearch \& Develoment. (Jakarta:PT Raja Grafindo Persada)

Rahmad Darmawan. 2012. Jadi Juara dengan Sepakbola Possession. (Jakarta:KickOff Media RD Books)

Tenang, Jhon D. 2008. Mahir Bermain Futsal. (Bandung: DAR! Mizan 